\title{
A study of prevalence of Vitamin D deficiency among pregnant women and its impact on feto maternal outcome
}

\author{
Shailaja Nageshu' ${ }^{1}$, Kirtan Krishna ${ }^{1}$, Krishna L. , B. Shyamasundara Bhat ${ }^{1}$, H. R. Suma ${ }^{2}$, \\ Surekha Reddy ${ }^{1}$
}

\author{
${ }^{1}$ Department of OBG, PES Institute of Medical Sciences and Research, Kuppam, Chittoor, Andhra Pradesh India \\ ${ }^{2}$ Department of Biochemistry, PES Institute of Medical Sciences and Research, Kuppam, Chittoor, Andhra Pradesh \\ India
}

Received: 12 February 2016

Accepted: 08 March 2016

\author{
*Correspondence: \\ Dr. Kirtan Krishna, \\ E-mail: kirtank1@gmail.com
}

Copyright: () the author(s), publisher and licensee Medip Academy. This is an open-access article distributed under the terms of the Creative Commons Attribution Non-Commercial License, which permits unrestricted non-commercial use, distribution, and reproduction in any medium, provided the original work is properly cited.

\begin{abstract}
Background: The aim of our study was to determine the prevalence of vitamin D among pregnant women and its impact on feto maternal outcome.

Methods: An observational study was conducted among 80 pregnant women at PESIMSR, Kuppam over a period of one month from first September 2014 to 30th September 2014. Our primary outcome was to study prevalence of Vitamin D deficiency in pregnant women and secondary outcome to study maternal and fetal outcome in pregnant women with Vitamin D deficiency. The subjects participating in the study were requested to complete a questionnaire that covered socio-demographic data, religion, obstetric history, lifestyle, dietary habits and psychosocial factors. Reliable serum 25-hydroxyvitamin D $(25(\mathrm{OH}) \mathrm{D})$ level was measured using an enzyme immunoassay method in the extra nine ml blood sample. Data on date of delivery, baby sex, birth weight, length and gestational age (based on ultrasound or on the timing of the last menstrual period) were collected prospectively.

Results: In the study period of the 80 women recruited, $3.8 \%$ were Christians, $78.8 \%$ were Hindus and $17.4 \%$ were Muslims. All women recruited for the study were $>32$ wks gestation. It was found that $53.8 \%$ had insufficient serum $25(\mathrm{OH}) \mathrm{D}$ concentrations and $13.8 \%$ were deficient for vitamin D. The lowest $25(\mathrm{OH}) \mathrm{D}$ concentrations (insufficient levels) were found in those with only one-two hours of sun exposure $(65.1 \%)$, and $54.5 \%$ had deficient levels. Highest concentrations $(11.5 \%)$ were found in those with two-four hours of sun exposure. There were no significant associations between $25(\mathrm{OH}) \mathrm{D}$ concentrations and maternal outcome. The analysis showed a significant association between a deficient vitamin D status $(45.5 \%)$ and low birth weight $(<2.5 \mathrm{Kg})$ compared to $15.4 \%$ who had normal vitamin D levels. An insufficient vitamin D status was also related to a lower birth weight, but the association was not statistically significant. Among babies born to study subjects $84.6 \%$ had a normal birth weight of $2.5-3.5 \mathrm{~kg}$ with normal maternal vitamin D levels, when compared to $36.4 \%$ with deficient maternal vitamin D levels. We did not find any significant association between Vitamin D levels and neonatal complications.

Conclusions: In our pilot study we found that prevalence of vitamin D deficiency was very high. Our sample size was too small to comment on impact of vitamin D deficiency on fetomaternal outcome. Hence we stopped our study and considered universal supplementation to all pregnant women.
\end{abstract}

Keywords: Vitamin D, Pregnancy, Low birth weight, Preeclampsia, Preterm, GDM

\section{INTRODUCTION}

Vitamin D deficiency during pregnancy is a worldwide epidemic; studies have reported a prevalence that ranges from $18-84 \%$, depending on the country \& local clothing customs. $^{1-5}$ Vitamin D deficiency is common in darkskinned persons, veiled populations living at various latitudes and inadequate vitamin D intake in women of 
child bearing age, during pregnancy, in nursing mothers with likely adverse consequences for women, the fetus and growing infants and children. ${ }^{2,5-13}$

The interaction of $1,25(\mathrm{OH}) 2 \mathrm{D}$ with nuclear vitamin $\mathrm{D}$ receptors influences gene transcription. Nuclear receptors for $1,25(\mathrm{OH}) 2 \mathrm{D}$ are present in a range of tissues including bone, intestine, kidney, lung, muscle and skin. Similar to steroid hormones, $1,25(\mathrm{OH}) 2 \mathrm{D}$ acts via signal transduction pathways linked to vitamin $\mathrm{D}$ receptors on cell membranes. Major sites of action include intestine, bone, parathyroid, liver and pancreatic beta cells. Its biological actions include increases in intestinal calcium absorption, transcellular calcium flux and opening gated calcium channels allowing calcium uptake into cells such as osteoblasts and skeletal muscle. Vitamin D has an increasingly recognised repertoire of non-classical actions, such as promoting insulin action and secretion, immune modulation and lung development. It inhibits PTH secretion and adaptive immunity, while promoting insulin secretion and innate immunity. It also inhibits cell proliferation and stimulates their differentiation. ${ }^{14}$

The largest source of vitamin D in adults is synthesis from solar radiation; half an hour of sunlight delivers 50 000 IU of vitamin D with white-complexioned skin. ${ }^{15}$ Melanin absorbs ultraviolet B (UVB) from sunlight and diminishes cholecalciferol production by at least $90 \% .^{16}$ Dietary intake of vitamin D makes a relatively small contribution to overall vitamin D status as there is little vitamin D that occurs naturally in the food supply. Dietary vitamin D is absorbed from the intestine and circulates in plasma bound to a vitamin $\mathrm{D}$ binding protein. $^{14}$

During pregnancy \& lactation, significant changes in maternal \& vitamin D and calcium metabolism occur to provide the calcium that is needed for fetal bone accretion. During the first trimester, the fetus accumulates $2-3 \mathrm{mg} / \mathrm{dl}$ in the skeleton; however the rate of accumulation doubles in the last trimester. ${ }^{17}$ Calcium levels are normal in utero when maternal vitamin $\mathrm{D}$ is insufficient because the maternal gut adapts and can overcome some vitamin D insufficiency with increased calcium transport. However, when maternal calcium delivery is interrupted at birth, the neonate may develop hypocalcaemia. ${ }^{14}$

Vitamin D status is usually estimated by measuring the levels of plasma 25(OH)D. Studies have developed a classification of stages for vitamin D status in nonpregnant adults (Table 1)that indicate that levels $>32 \mathrm{ng} / \mathrm{ml}$ are required for adequacy. ${ }^{18,19}$ These stages correlate with maternal and fetal outcomes, which suggests that they also apply in pregnancy and during lactation. $^{20}$

There is little information on vitamin $\mathrm{D}$ intake in pregnancy and lactation and few studies on clinical outcomes. Some have suggested that the requirement for vitamin D in these women may be up to $6000 \mathrm{IU} /$ day and the ideal vitamin $\mathrm{D}$ regimen to prevent and treat vitamin $\mathrm{D}$ insufficiency in utero is unknown. ${ }^{21}$ The aim of our study was to ascertain the prevalence of vitamin D among pregnant women and its impact on feto maternal outcome.

\section{METHODS}

An observational study was conducted among 80 pregnant women at PESIMSR, Kuppam over a period of one month from first September 2014 to $30^{\text {th }}$ September 2014. Our primary outcome was to study the prevalence of Vitamin D deficiency in pregnant women and secondary outcome was to study maternal and fetal outcome in pregnant women with Vitamin D deficiency. Ethical clearance was obtained from the institutional ethical committee.

During the study period, pregnant women aged 18-35yrs old with gestational age $>28$ weeks attending the antenatal clinic \& labour room were recruited for the study after taking a written and informed consent.

Women with pre-existing medical disorders were excluded from the study.

The pregnant women participating in the study were requested to complete a questionnaire that covered sociodemographic data, religion, obstetric history, lifestyle, dietary habits and psychosocial factors. For this study, an extra blood sample (nine $\mathrm{ml}$ ) was taken during routine blood collection at the first prenatal check-up. Reliable serum vitamin $\mathrm{D}$ was measured in the extra blood sample using an enzyme immunoassay method. Data on date of delivery, infant sex, birth weight, length and gestational age (based on ultrasound or on the timing of the last menstrual period) were collected prospectively.

Measurement of vitamin D (Independent variable) was done by an enzyme immunoassay method. At the laboratory, serum was prepared by centrifugation (1600 revolutions per minute for $10 \mathrm{~min}$ at room temperature), and stored as one $\mathrm{ml}$ aliquots at $280^{\circ} \mathrm{C}$ until analysis. Serum 25-hydroxyvitamin D $(25(\mathrm{OH})$ D) level was measured using an enzyme immunoassay method. Vitamin D measurements outside the detection range (6$544 \mathrm{nmol} / \mathrm{l}$ ) were excluded from the analyses. Reliability was checked using the HIL index: Serum specimens may contain $\mathrm{Hb}(\mathrm{H}$, haemolysis), bilirubin (I, icterus) and lipids (L, lipaemia) that can adversely impact clinical chemistry tests. When these interferents had values of H.1400, I.30 and/or L.250, the data were considered unreliable. Since there were no unreliable records, all samples were included for the analysis.

Outcome variables were birth weight, small for gestational age (SGA) and neonatal weight and length trajectories of neonates born at term (gestational age 37 weeks or more). An infant was considered SGA when his 
or her birth weight fell below the $10^{\text {th }}$ percentile of the most recent Indian reference values for that gestational age according to parity and sex. Neonatal weight and length trajectories were calculated by transforming each measurement into sex and age-specific standard deviation scores (SDS) based on the total research population.

\section{Statistical analysis}

Descriptive and inferential statistical analysis has been carried out in the present study. Results on continuous measurements are presented as Mean \pm SD (Min-Max) and results on categorical measurements are presented in Number (\%). Significance is assessed at $5 \%$ level of significance. The following assumptions on data are made:
1. Dependent variables should be normally distributed

2. Samples drawn from the population should be random; cases of the samples should be independent.

Chi-square/ Fisher Exact test has been used to find the significance of study parameters on categorical scale between two or more groups. All analyses were performed by using SPSS software (version 12.0.1, SPSS Inc, Chicago, IL).

\section{RESULTS}

Table 1: Feto Maternal effects of vitamin D deficiency.

\begin{tabular}{|c|c|c|c|}
\hline Stage & $\begin{array}{l}\text { Serum } 25 \text { (OH) } \\
\text { D, ng/ml }\end{array}$ & Maternal adverse effects & New born infant adverse effects \\
\hline Severe deficiency & $<10$ & $\begin{array}{l}\text { Increased risk of pre } \\
\text { eclampsia, calcium } \\
\text { malabsorption, bone loss, } \\
\text { poor weight gain, myopathy, } \\
\text { higher parathormone levels }\end{array}$ & $\begin{array}{l}\text { Small for gestational age, neonatal } \\
\text { hypocalcemia, hypocalcemic seizures, infantile } \\
\text { heart failure, enamel defects, large fontanelle, } \\
\text { congenital rickets, rickets of infancy if } \\
\text { breastfed }\end{array}$ \\
\hline Insufficiency & $11-32$ & $\begin{array}{l}\text { Bone loss, subclinical } \\
\text { myopathy }\end{array}$ & $\begin{array}{l}\text { Neonatal hypocalcemia, reduced bone mineral } \\
\text { density, rickets of infancy if breast fed }\end{array}$ \\
\hline Adequacy & $32-100$ & $\begin{array}{l}\text { Adequate calcium balance, } \\
\text { parathormone levels }\end{array}$ & None, unless exclusively breastfed \\
\hline Toxicity & $>100$ & $\begin{array}{l}\text { Hypercalcemia, increased } \\
\text { urine calcium loss }\end{array}$ & Infantile idiopathic hypercalcemia \\
\hline
\end{tabular}

In the period from first September 2014 to $30^{\text {th }}$ September 2014, 80 women who came to the labour room or antenatal clinic agreed to participate in the study. Of these women, $3.8 \%$ were Christians, $78.8 \%$ were Hindus and $17.4 \%$ were Muslims. They belonged to the age group of 18 -35 yrs. Among study subjects $43 \%$ were multigravidae and $56.2 \%$ were primigravidae. All women recruited for the study were $>32$ wks gestation. The relation between vitamin $\mathrm{D}$ and ethnicity was not confounded by socio economic status, religion, or parity (Table 2).

It was found that $53.8 \%$ had insufficient Serum $25(\mathrm{OH})$ D concentrations and $13.8 \%$ were deficient for Vit D (Table 3, Figure 1).

The lowest 25(OH) D concentrations (insufficient levels) were found in those with only 1-2 hrs of sun exposure $(65.1 \%)$, and $54.5 \%$ had deficient levels. Highest concentrations $(11.5 \%)$ were found in those with $2-4 \mathrm{hrs}$ of sun exposure (Table 4, Figure 2).

\begin{tabular}{|ll|}
\hline Variable & $\%$ \\
\hline Age: $18-35$ & 100 \\
\hline Religion & \\
Christian & $3.8 \%$ \\
Hindu & $78.8 \%$ \\
Muslim & $17.4 \%$ \\
\hline Parity & \\
Multi & $43.3 \%$ \\
Primi & $56.2 \%$ \\
\hline Gestational age & \\
<32wks & 0 \\
$32-37$ wks & $15 \%$ \\
$37-40$ wks & $56.3 \%$ \\
$>40$ wks & $28.8 \%$ \\
\hline BMI & \\
Underweight & $1.2 \%$ \\
Normal & $55 \%$ \\
Overweight & $43.8 \%$ \\
Obese & $0 \%$ \\
\hline
\end{tabular}

Table 3: Vitamin D3 levels in patients studied.

Table 2: Demographic data. 


\begin{tabular}{|c|c|c|}
\hline Vitamin D3 & No. of patients & $\%$ \\
\hline Normal & 26 & 32.5 \\
\hline Insufficiency & 43 & 53.8 \\
\hline Deficiency & 11 & 13.8 \\
\hline Total & 80 & 100.0 \\
\hline
\end{tabular}

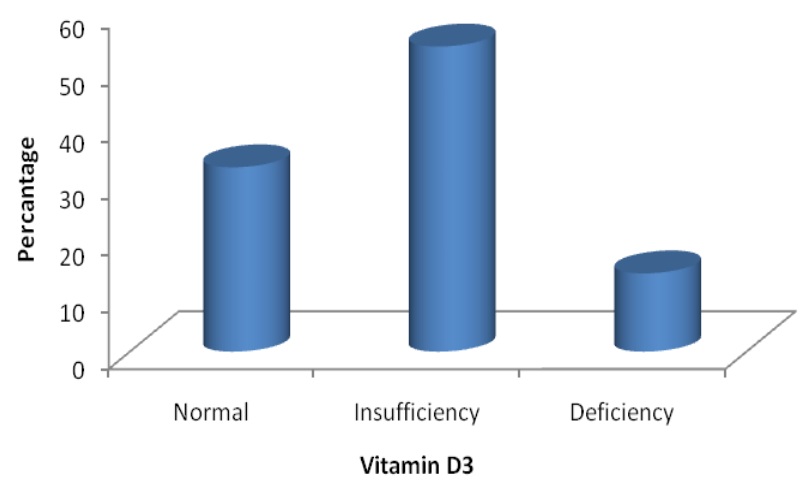

Figure 1: Vitamin D3 levels in patients studied.

Table 4: Correlation of duration of exposure to sun according to Vitamin D3 levels in patients studied.

\begin{tabular}{|lllll|}
\hline $\begin{array}{l}\text { Duration } \\
\text { of } \\
\text { exposure } \\
\text { to sun }\end{array}$ & $\begin{array}{l}\text { Vitamin D3 } \\
\text { Normal }\end{array}$ & $\begin{array}{l}\text { Insuffi- } \\
\text { ciency }\end{array}$ & $\begin{array}{l}\text { Defici- } \\
\text { ency }\end{array}$ & \\
\hline $\begin{array}{l}<1 / 2 \\
\text { hour }\end{array}$ & 3 & 6 & 2 & 11 \\
\hline $1-2$ & $(11.5 \%)$ & $(14 \%)$ & $(18.2 \%)$ & $(13.8 \%)$ \\
\hline $2-3$ & 3 & 28 & 6 & 51 \\
& $(65.4 \%)$ & $(65.1 \%)$ & $(54.5 \%)$ & $(63.8 \%)$ \\
\hline $3-4$ & 3 & 6 & 1 & 10 \\
& $(11.5 \%)$ & $(14 \%)$ & $(9.1 \%)$ & $(12.5 \%)$ \\
\hline Total & 26 & 3 & 2 & 8 \\
& $(100 \%)$ & $(100 \%)$ & $(100 \%)$ & $(100 \%)$ \\
\hline
\end{tabular}

$\mathrm{P}=0.918$, Not significant, Chi-square test

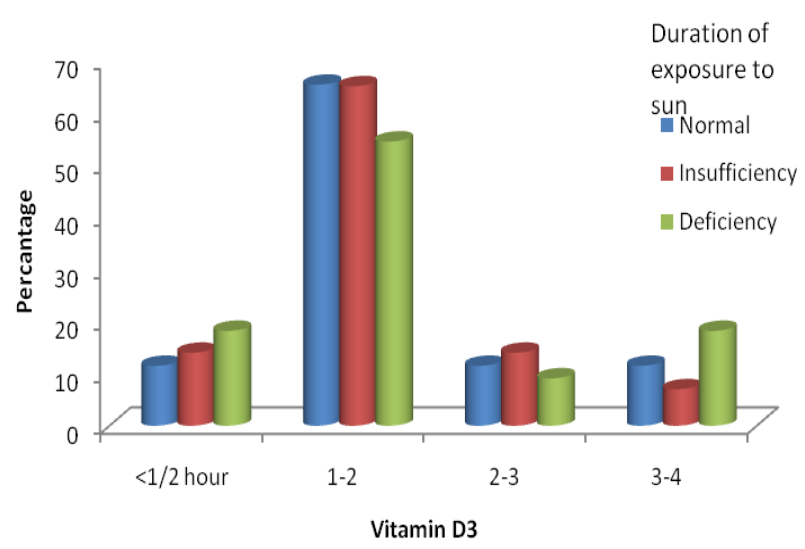

Figure 2: Correlation of Duration of exposure to sun according to Vitamin D3 levels in patients studied.
It was found that $64 \%$ of women studied took regular calcium supplementation throughout pregnancy (Figure 3).

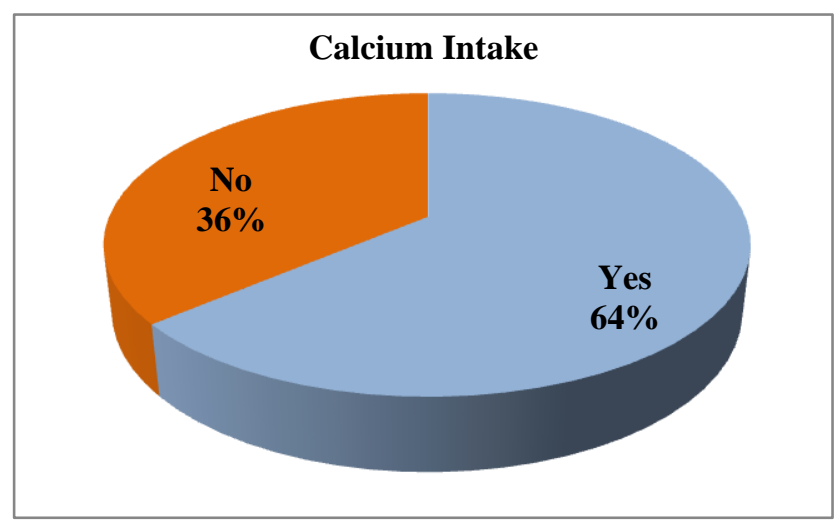

Figure 3: Calcium intake in patients studied.

There were no significant association between $25(\mathrm{OH}) \mathrm{D}$ concentrations and maternal outcome. While $92.3 \%$ with normal vitamin D levels had no complications, $81.8 \%$ with deficient levels were uncomplicated. However, among women with hypovitaminosis D, 16\% developed PIH, $15.2 \%$ had pre term birth \& $2.3 \%$ developed GDM (Table 5).

Table 5: Maternal complications according to Vitamin D2 levels in subjects studied.

\begin{tabular}{|c|c|c|c|c|}
\hline \multirow{2}{*}{$\begin{array}{l}\text { Maternal } \\
\text { complicati } \\
\text { ons }\end{array}$} & \multicolumn{3}{|c|}{ Vitamin D3 } & \multirow{2}{*}{$\begin{array}{l}\text { Total } \\
(n=80)\end{array}$} \\
\hline & $\begin{array}{l}\text { Normal } \\
(n=26)\end{array}$ & $\begin{array}{l}\text { Insuffi- } \\
\text { ciency } \\
(n=43)\end{array}$ & $\begin{array}{l}\text { Defici- } \\
\text { ency } \\
(n=11)\end{array}$ & \\
\hline No & $\begin{array}{l}24 \\
(92.3 \%)\end{array}$ & $\begin{array}{l}39 \\
(90.7 \%)\end{array}$ & $\begin{array}{l}9 \\
(81.8 \%)\end{array}$ & $\begin{array}{l}72 \\
(90 \%)\end{array}$ \\
\hline Yes & $\begin{array}{l}2 \\
(7.7 \%)\end{array}$ & $\begin{array}{l}4 \\
(9.3 \%)\end{array}$ & $\begin{array}{l}2 \\
(18.2 \%)\end{array}$ & $\begin{array}{l}8 \\
(10 \%)\end{array}$ \\
\hline $\begin{array}{l}\text { Abruption } \\
\text { placenta }\end{array}$ & $\begin{array}{l}0 \\
(0 \%)\end{array}$ & $\begin{array}{l}1 \\
(2.3 \%)\end{array}$ & $\begin{array}{l}1 \\
(9.1 \%)\end{array}$ & $\begin{array}{l}2 \\
(2.5 \%)\end{array}$ \\
\hline GDM & $\begin{array}{l}0 \\
(0 \%)\end{array}$ & $\begin{array}{l}1 \\
(2.3 \%)\end{array}$ & $\begin{array}{l}0 \\
(0 \%)\end{array}$ & $\begin{array}{l}1 \\
(1.3 \%)\end{array}$ \\
\hline $\mathrm{PIH}$ & $\begin{array}{l}0 \\
(0 \%)\end{array}$ & $\begin{array}{l}3 \\
(6.9 \%)\end{array}$ & $\begin{array}{l}1 \\
(9.1 \%)\end{array}$ & $\begin{array}{l}4 \\
(5 \%)\end{array}$ \\
\hline $\begin{array}{l}\text { Oligohyd- } \\
\text { ramnios }\end{array}$ & $\begin{array}{l}1 \\
(3.8 \%)\end{array}$ & $\begin{array}{l}0 \\
(0 \%)\end{array}$ & $\begin{array}{l}0 \\
(0 \%)\end{array}$ & $\begin{array}{l}1 \\
(1.3 \%)\end{array}$ \\
\hline Pre term & $\begin{array}{l}3 \\
(11.5 \%)\end{array}$ & $\begin{array}{l}5 \\
(11.6 \%)\end{array}$ & $\begin{array}{l}4 \\
(3.6 \%)\end{array}$ & $\begin{array}{l}12 \\
(15 \%)\end{array}$ \\
\hline
\end{tabular}

$\mathrm{P}=0.673$, Not significant, Fisher exact test

The analyses showed a significant association between a deficient vitamin D status $(45.5 \%)$ and low birth weight $(<2.5 \mathrm{Kg})$ compared to $15.4 \%$ who had normal vitamin D levels. An insufficient vitamin D status was also related to a lower birth weight, but the association was not significant. Among normal birth weight (2.5-3.5 Kg) babies $84.6 \%$ of mothers had normal vitamin $\mathrm{D}$ status and $36.4 \%$ of them had deficient vitamin D levels (Table 6). 
Table 6: Correlation of Birth weight (kg) according to Vitamin D2 levels in subjects studied.

\begin{tabular}{|lllll|}
\hline $\begin{array}{l}\text { Birth } \\
\text { weight } \\
(\mathrm{kg})\end{array}$ & $\begin{array}{l}\text { Vitamin } \\
\text { Normal }\end{array}$ & $\begin{array}{l}\text { Insuffi- } \\
\text { ciency }\end{array}$ & $\begin{array}{l}\text { Defic- } \\
\text { iency }\end{array}$ & \\
\hline$<2.5$ & 4 & 9 & 5 & 18 \\
& $(15.4 \%)$ & $(20.9 \%)$ & $(45.5 \%)$ & $(22.5 \%)$ \\
\hline $2.5-3.5$ & 22 & 33 & 4 & 60 \\
& $(84.6 \%)$ & $(76.7 \%)$ & $(36.4 \%)$ & $(75 \%)$ \\
\hline $3.5-4.5$ & 1 & 1 & 2 & 2 \\
& $(3.8 \%)$ & $(2.3 \%)$ & $(18.2 \%)$ & $(2.5 \%)$ \\
\hline Total & 26 & 43 & 11 & 80 \\
& $(100 \%)$ & $(100 \%)$ & $(100 \%)$ & $(100 \%)$ \\
\hline
\end{tabular}

$\mathrm{P}=0.033+$, Significant, Fisher exact test

We did not find any significant association between Vitamin D levels and neonatal complications (Table 7).

Table 7: Fetal complications according to Vitamin D2 levels in subjects studied.

\begin{tabular}{|lllll|}
\hline $\begin{array}{l}\text { Fetal } \\
\text { complications }\end{array}$ & $\begin{array}{l}\text { Vitamin } \\
\text { Normal } \\
\text { (n=26) }\end{array}$ & $\begin{array}{l}\text { Insuffi- } \\
\text { ciency } \\
(\mathbf{n = 4 3})\end{array}$ & $\begin{array}{l}\text { Defici- } \\
\text { ency } \\
(\mathbf{n = 1 1})\end{array}$ & $\begin{array}{l}\text { Total } \\
(\mathbf{n}=80)\end{array}$ \\
\hline No & $\begin{array}{l}25 \\
(96.2 \%)\end{array}$ & 38 & 8 & 71 \\
& $(88.4 \%)$ & $(72.7 \%)$ & $(88.8 \%)$ \\
\hline Yes & 1 & 5 & 3 & 9 \\
& $(3.8 \%)$ & $(11.6 \%)$ & $(27.3 \%)$ & $(11.3 \%)$ \\
\hline IUGR & 0 & 1 & 0 & 1 \\
& $(0 \%)$ & $(2.3 \%)$ & $(0 \%)$ & $(1.3 \%)$ \\
\hline NICU & 1 & 4 & 3 & 8 \\
& $(3.8 \%)$ & $(9.3 \%)$ & $(27.3 \%)$ & $(10 \%)$ \\
\hline
\end{tabular}

$\mathrm{P}=0.128$, Not Significant, Fisher exact test

\section{DISCUSSION}

Prevalence of vitamin D deficiency varies widely across various populations. International comparison of the prevalence of Vitamin D deficiency is difficult because of variation in the definition of vitamin $\mathrm{D}$ deficiency in reported studies. Also prevalence of vitamin D deficiency is influenced by ethnicity, food habits, clothing, climate and exposure to sun.

Vitamin D deficiency is common in Northern Europe, especially in women with pigmented skin. Vitamin D deficiency is three times more common in the winter and spring compared to the summer and autumn in the $\mathrm{UK}^{22}$ In a London antenatal population, a vitamin $\mathrm{D}$ level of less than $25 \mathrm{nmol} / \mathrm{l}$ was found in $47 \%$ of Indian Asian women, $64 \%$ of Middle Eastern women, $58 \%$ of black women and $13 \%$ of Caucasian women. ${ }^{15}$

Pre-eclampsia and neonatal hypocalcaemia are the most prevalent complications of maternal hypocalcaemia and are clearly associated with substantial morbidity. A statistical association of glucose intolerance and hypovitaminosis $\mathrm{D}$ has been demonstrated. Maternal vitamin $\mathrm{D}$ is important to fetal bone development. ${ }^{23,24}$ Fetal lung development and neonatal immune conditions such as asthma may relate in part to maternal vitamin D levels. Although it is not clear whether maternal vitamin D supplementation will prevent these conditions, a strategy for supplementation and treatment of maternal vitamin D deficiency is proposed. ${ }^{14}$

There are no data to support routine screening for vitamin $\mathrm{D}$ deficiency in pregnancy in terms of health benefits or cost effectiveness. There is an argument that some groups of women who are pregnant should have a screening test: for example, on the basis of skin colour or coverage, obesity, risk of pre-eclampsia, or gastroenterological conditions limiting fat absorption. As the test is expensive, offering it to all at-risk women may not be cost effective compared to offering universal supplementation, particularly as treatment is regarded as being very safe. At present, there are no data to support a strategy of measurement followed by treatment in the general female population. ${ }^{25}$ Measurement of vitamin D in a hypocalcaemic or symptomatic woman as part of their management continues to be applicable. This includes women with a low calcium concentration, bone pain, gastrointestinal disease, alcohol abuse, a previous child with rickets and those receiving drugs which reduce vitamin D.

Treatment of vitamin D deficient women and vitamin $\mathrm{D}$ supplementation is safe and is recommended for all women who are pregnant or breastfeeding. Low vitamin $\mathrm{D}$ concentrations are present in a significant proportion of the population. A review and meta-analysis by Aghajafari et al. found associations between vitamin D insufficiency and risk of gestational diabetes, pre-eclampsia, bacterial vaginosis and SGA infants. ${ }^{26}$ However, despite a dearth of interventional evidence supporting supplementation/treatment of vitamin D in randomised controlled trial settings, it is generally accepted that supplementation/treatment is not harmful and may have some significant short- and long-term health benefits. The 2012 recommendation from UK Chief Medical Officers and NICE guidance state that all pregnant and breastfeeding women should be informed about the importance of vitamin D and should take 10 micrograms of vitamin D supplements daily. ${ }^{27,28}$ This does not necessarily demonstrate that correction during pregnancy will reduce these risks.

Three categories of vitamin D supplementation are recommended by RCOG.

1. In general, vitamin D 10 micrograms (400 units) a day is recommended for all pregnant women. ${ }^{27}$

2. High-risk women are advised to take at least 1000 units a day (women with increased skin pigmentation, reduced exposure to sunlight, or those who are socially excluded or obese). ${ }^{21,29}$ 
3. Treatment for the majority of women who are deficient in vitamin $\mathrm{D}$, treatment for four-six weeks, either with cholecalciferol 20000 IU a week or ergocalciferol 10000 IU twice a week, followed by standard supplementation, is appropriate. $^{30,31}$ A 2011 study demonstrated that supplemental doses of 4000 IU cholecalciferol a day were safe in pregnant women and most effective compared to the lower doses. ${ }^{32}$

Vitamin D may be inappropriate in sarcoidosis (where there may be vitamin D sensitivity) or ineffective in renal disease. Deficient renal 1- $\alpha$ hydroxylation necessitates the use of active vitamin D metabolites, such as $1 \alpha-$ hydroxycholecalciferol or 1 , 25dihydroxycholecalciferol. Specialist medical advice should be sought in such cases. ${ }^{33,34}$

In pregnancy there is enhanced intestinal calcium absorption. Vitamin D toxicity is manifested through hypercalcaemia and hypercalciuria. Therefore, there is a hypothetical concern that when secondary hyperparathyroidism follows vitamin D deficiency, calcium given with vitamin D may be associated with temporary hypercalcaemia. However, this is self-limiting due to the associated hungry bone and has not been demonstrated to represent a clinical problem. ${ }^{14}$

\section{CONCLUSIONS}

Treatment of vitamin D deficient women and vitamin D supplementation is safe and is recommended for all women who are pregnant or breastfeeding. Low vitamin $\mathrm{D}$ concentrations are present in a significant proportion of our population. Further research should focus on the potential benefits and optimal dosing of vitamin $\mathrm{D}$ use in pregnancy. Ours was a pilot study. We found vitamin D deficiency prevalence to be very high in our population. Our sample size is too small to comment on impact of vitamin D deficiency on fetomaternal outcome. Hence we stopped our study and considered universal supplementation to all pregnant women. This universal supplementation of vitamin D is more cost effective and acceptable to our population.

\section{ACKNOWLEDGEMENT}

We thank the management of PESIMSR for permitting us to use the laboratory services and clinical material of the institution.

\section{Funding: No funding sources} Conflict of interest: None declared

Ethical approval: The study was approved by the Institutional Ethics Committee

\section{REFERENCES}

1. Dawodu A, Wagner CL. Mother-child vitamin D deficiency: an international perspective. Arch Dis Child. 2007;92:737-40.

2. Van der Meer IM, Karamali NS, Boeke AJ. High prevalence of vitamin D deficiency in pregnant nonWestern women in The Hague, Netherlands. Am J Clin Nutr. 2006;84:350-9.

3. Bassir M, Laborie S, Lapillonne A, Claris O, Chappuis MC, Salle BL. Vitamin D deficiency in Iranian mothers and their neonates: a pilot study. Acta Paediatr. 2001;90:577-9.

4. Markestad T, Elzouki A, Legnain M, Ulstein M, Aksnes L. Serum concentrations of vitamin D metabolites in maternal and umbilical cord blood of Libyan and Norwegian women. Hum Nutr Clin Nutr. 1984;38:55-62.

5. Sachan A, Gupta R, Das V, Agarwal A, Awasthi PK, Bhatia V. High prevalence of vitamin D deficiency among pregnant women and their newborns in northern India. Am J Clin Nutr. 2005;81:1060-4.

6. Bodnar LM, Simhan HN, Powers RW. High prevalence of Vitamin D insufficiency in black and white pregnant women residing in the northern United states and their neonates. J Nutr. 2007;137:447-52.

7. Nesby-O'Dell S, Scanlon K, Cogswell M. Hypovitaminosis D prevalence and determinants among African American and white women of reproductive age: Third National Health and Nutrition Examination Survey: 1988-1994. Am J Clin Nutr. 2002;76:187-92.

8. Dawodu A, Absood G, Patel M. Biosocial factors affecting vitamin D status of women of childbearing age in the United Arab Emirates. J Biosoc Sci. 1998;30:431-7.

9. Mashal AA. Effects of different dress styles on vitamin D levels in healthy young Jordanian women. Osteoporos Int. 2001;12:931-5.

10. Hollis BW, Wagner CL. Assessment of dietary vitamin $\mathrm{D}$ requirements during pregnancy and lactation. Am J Clin Nutr. 2004;79:717-26.

11. Grover SR, Morley R. Vitamin D deficiency in veiled or dark-skinned pregnant women. Med J Aust 2001;175:251-2.

12. Dawodu A, Agarwal M, Hossain M. Hypovitaminosis D and vitamin D deficiency in exclusively breast-feeding infants and their mothers in summer: a justification for vitamin D supplementation of breast-feeding infants. J Pediatr. 2003;142:169-73.

13. Challa A, Ntourntoufi A, Cholevas V. Breastfeeding and vitamin D status in Greece during the first 6 months of life. Eur J Pediatr. 2005;164(12):724-9.

14. Vitamin D in Pregnancy. RCOG Scientific Impact Paper No. 43. 2014:2,3. 
15. Yu CK, Sykes L, Sethi M, Teoh TG, Robinson S. Vitamin D deficiency and supplementation during pregnancy. Clin Endocrinol (Oxf). 2009;70:685-90.

16. Clemens TL, Henderson SL, Adams JS, Holick MF. Increased skin pigment reduces the capacity of skin to synthesise vitamin D3. Lancet. 1982;i:74-6.

17. Abrams SA. In utero physiology: role in nutrient delivery and fetal development for calcium, phosphorus, and vitamin D. Am J Clin Nutr. 2007;85:604S-7S.

18. Zittermann A, Schleithoff SS, Koerfer R. Putting cardiovascular disease and vitamin D insufficiency into perspective. Br J Nutr. 2005;94:483-92.

19. Hollis BW. Circulating 25-hydroxyvitamin D levels indicative of vitamin D sufficiency: implications for establishing a new effective dietary intake recommendation for vitamin D. J Nutr. 2005;135:317-22.

20. Hollis BW, Wagner CL. Vitamin D deficiency during pregnancy: an on-going epidemic. Am J Clin Nutr. 2006;84:273.

21. Hollis BW. Vitamin D requirement during pregnancy and lactation. $\mathrm{J}$ Bone Miner Res. 2007;22(2):39-44.

22. Hyppönen E, Power C. Hypovitaminosis D in British adults at age $45 \mathrm{y}$ : nationwide cohort study of dietary and lifestyle predictors. Am J Clin Nutr. 2007;85:860-8.

23. Morley R, Carlin JB, Pasco JA, Wark JD. Maternal 25-hydroxyvitamin $\mathrm{D}$ and parathyroid hormone concentrations and offspring birth size. J Clin Endocrinol Metab. 2006;91:906-12.

24. Mahon P, Harvey N, Crozier S, Inskip H, Robinson $\mathrm{S}$, Arden N, et al. Low maternal vitamin D status and fetal bone development: cohort study. J Bone Miner Res. 2010;25:14-9.

25. Sattar N, Welsh P, Panarelli M, Forouhi NG. Increasing requests for vitamin $\mathrm{D}$ measurement: costly, confusing, and without credibility. Lancet. 2012;379:95-6.

26. Aghajafari F, Nagulesapillai T, Ronksley PE, Tough SC, O'Beirne M, Rabi DM. Association between maternal serum 25-hydroxyvitamin D level and pregnancy and neonatal outcomes: systematic review and meta-analysis of observational studies. BMJ. 2013;346:f1169.

27. Chief Medical Officers for the United Kingdom. Vitamin D - advice on supplements for at risk groups. Cardiff, Belfast, Edinburgh, London: Welsh Government, Department of Health, Social Services and Public Safety, The Scottish Government, Department of Health. 2012. [http://www.scotland.gov.uk/Resource/0038/003869 21.pdf].

28. National Institute for Health and Clinical Excellence. Antenatal care. NICE clinical guideline 62. Manchester: NICE. 2008.

29. Dawson-Hughes B, Heaney RP, Holick MF, Lips P, Meunier PJ, Vieth R. Estimates of optimal vitamin D status. Osteoporos Int. 2005;16:713-6.

30. Saadi HF, Dawodu A, Afandi BO, Zayed R, Benedict S, Nagelkerke N. Efficacy of daily and monthly high-dose calciferol in vitamin D-deficient nulliparous and lactating women. Am J Clin Nutr. 2007;85:1565-71.

31. Kennel KA, Drake MT, Hurley DL. Vitamin D deficiency in adults: when to test and how to treat. Mayo Clin Proc. 2010;85:752-7.

32. Hollis BW, Johnson D, Hulsey TC, Ebeling M, Wagner CL. Vitamin D supplementation during pregnancy: double-blind, randomized clinical trial of safety and effectiveness. J Bone Miner Res. 2011;26:2341-57.

33. Ito M, Koyama H, Ohshige A, Maeda T, Yoshimura T, Okamura H. Prevention of preeclampsia with calcium supplementation and vitamin D3 in an antenatal protocol. Int $\mathbf{J}$ Gynaecol Obstet. 1994;47:115-20.

34. Hofmeyr GJ, Lawrie TA, Atallah AN, Duley L. Calcium supplementation during pregnancy for preventing hypertensive disorders and related problems. Cochrane Database Syst Rev. 2010;(8):CD001059.

Cite this article as: Nageshu S, Krishna K, Krishna L, Bhat S, Suma HR, Reddy S. A study of prevalence of Vitamin D deficiency among pregnant women and its impact on feto maternal outcome. Int J Reprod Contracept Obstet Gynecol 2016;5:1174- 